\title{
The influence of the extracellular concentration of glucose on the respiratory quotient of isolated tissue
}

\author{
JAMES M. O'CONNOR \\ University College, Dublin, Ireland
}

KURZFASSUNG: Der Einfluß der extrazellulären Konzentration von Glukose auf den Respiratorischen Quotienten isolierter Gewebe. Der Sauerstoffverbrauch yon Gewebeschnitten der Ratte unterliegt Schwankungen bei einer Temperaturänderung. In gleicher Weise variieren die Werte des Respiratorischen Quotienten (R.Q.), insbesondere im Bereich der normalen Körpertemperatur. Bei Rattennierenschnitten, die 2 Stunden kalter Ringerlösung mit verschiedenen Glukosekonzentrationen ausgesetzt waren, treten im Temperaturbereich von $40,5^{\circ}$ bis $37,5^{\circ} \mathrm{C}$ starke Oszillationen des R. Q. (von 0,65 bis 1,0) auf, jedoch nur, wenn die extrazelluläre Glukosekonzentration innerhalb der Grenzen des normalen Blutzuckergehalts liegt. Ahnliche Ergebnisse (mit grundsätzlich niedrigeren R. Q.-Werten) finden sich in der Niere alloxandiabetischer Ratten. Anhand statistischer Analysen läßt sich ein zweifacher Verlauf des R.Q. nachweisen: (1) bei niederen Werten besteht eine Kompetition zwischen Fettsäuren und Kohlenhydrat um den Sauerstoff; (2) bei einem R. Q. von 0,8 hört diese auf. Bis zu diesem Punkt findet die Oxydation innerhalb der Mitochondrien statt, deren Struktur auf einer amphiphilen kristallinen Verbindung von Fettsäuren und Lecithin beruht. Der teilweise Abbau dieser kristallinen Struktur unter dem Einfluß des Hydroxylgruppen enthaltenden Zudkermoleküls bringt den Zugang oxydierender Enzyme zu Glykolyseprodukten und damit das Auftreten hoher R.Q.-Werte mit sich.

\section{INTRODUCTION}

It has been shown by various methods that the oxygen consumption of animal tissues falls sharply at the temperature of the central body (O'CoNNOR 1959). Subsequently, it was found that this is one example of seven such changes, the positive phase of each being dependent on the coming into action of the normally occuring fatty acids in an homologous series (O'CONNOR 1955). These changes may be demonstrated in isolated tissue, but not if, as in the Warburg apparatus, the tissues had been exposed to warm Ringer solution. They have been demonstrated in a respirometer, in which the tissue slices are mounted on a "cradle" inserted into a tubular vessel; this vessel is lined with a roll of filter paper saturated with $0.17 \mathrm{~N} \mathrm{NaOH}$. The $\mathrm{NaOH}$ solution absorbs the $\mathrm{CO}_{2}$ and keeps the vapour pressure constant at the level of the physiological saline (O'Connor 1960). The respirometer is immersed in a bath, initially kept at body temperature, and the rate of movement of a kerosene meniscus, entered 
in the protocol as the temperature of the bath, is allowed to fall slowly. A second respircmeter in which the alkaline solution is substituted by a small volume of $\mathrm{HCl}$ of the same strength is also immersed in the bath. From the rate of movement of the meniscus of this respirometer, the rate of change of the difference between oxygen consumption and $\mathrm{CO}_{2}$ production is obtained, and from the simultaneous results of both apparatuses, the change in R.Q. is calculated. It is commonly found that this tends to oscillate in unison with the oxygen consumption; low R. Q.'s accompany high oxygen consumptions.

The core of the body in which a constant "central temperature" prevails is surrounded by an extensive region where a marked gradient of temperature occurs. Hence an R. Q. which prevails at the body core or at any other body part cannot represent the R. Q. of the whole animal. Apart from possible variations in different organs, the R.Q. of the whole animal must usually be an aggregate of widely varying values. It is necessary therefore to take into consideration the results over a range of temperatures approximately corresponding to that prevailing in the body.

There are, however, conditions in which the R.Q. of the whole animal is at, or close to, one end of the scale. In such cases the changes in R.Q. cannot be large or numerous. These considerations obviously apply only to such organs in which there are no massive interchanges between the main constituents.

\section{RESULTS AND DISCUSSION}

The experiments which are considered here were done on kidney slices (rat), in which such transformations, if they do normally occur, are not marked. The gaseous exchanges were followed over the range from $40.5^{\circ}$ to $37.5^{\circ} \mathrm{C}$. The time occupied in this fall of temperature was about $1 \frac{1}{2} 2$ hours, and the number of sets of observations was usually between 50 and 60 .

When a dose of insulin had been injected into the rat about half an hour before it was killed the R.Q. was usually found to be fixed within a narrow range (O'ConNor 1962). Subsequently it was found that if the tissue slices had been previously immersed in $3 \mathrm{ml}$ of cold Ringer solution containing varying concentrations of glucose, the R. Q. varied extensively over a limited range of glucose. But at concentrations above and below this range it was fixed (O'CONNOR 1964). The concentrations at which the R. Q. oscillated varied with the dose of insulin. With a dose of 2 units of insulin, the R. Q. was fixed when extracellular glucose concentration was $0,0.6$, and $1.0 \mathrm{~g}$ per $100 \mathrm{ml}$ Ringer, but it oscillated widely when the concentration of glucose was $0.3 \mathrm{~g} / 100 \mathrm{ml}$. With a dose of insulin of 8 units, the R.Q. was fixed with glucose concentrations 0.3 and $2.0 \mathrm{~g} /$ $100 \mathrm{ml}$ but oscillated when the concentrations were 0.6 and $1.0 \mathrm{~g} / 100 \mathrm{ml}$ (O'ConNoR 1964). From these results, it appeared probable that in the normal animal the R.Q. would oscillate in a similar manner but at lower glucose concentrations.

The results obtained in the normal rat are presented in Figure 1. It appears from Figure 1, I that extracellular glucose concentration must, in the normal animal, reach $70 \mathrm{mg} / 100 \mathrm{ml}$ before a high proportion of carbohydrate can be oxidized and that when the concentration passes $110 \mathrm{mg} / 100 \mathrm{ml}$, the ability to oxidise a high proportion of 
glucose disappears. The limits of these concentrations are in close correspondence with the normal range of blood glucose concentration.

In Figure 1, II the results of a similar series of experiments on the alloxan diabetic rat are presented. The zone of the initial glucose concentrations within which high

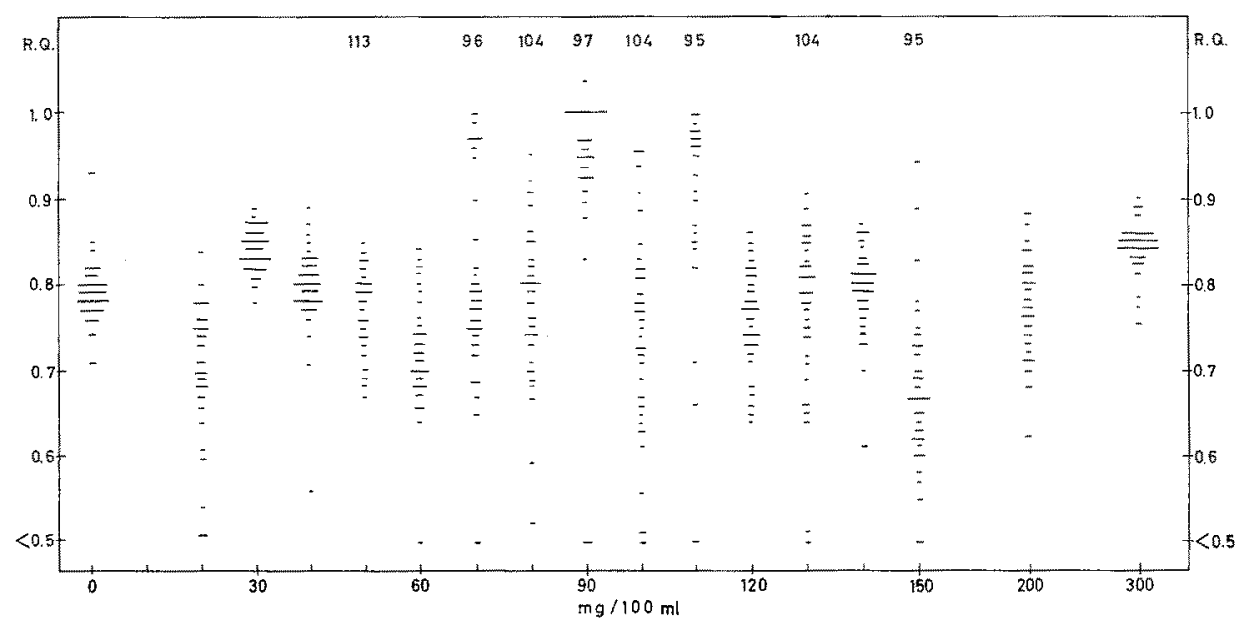

Fig. 1, I: Influence of extracellular concentration of glucose on the R. Q. of normal rat kidney slices. Abscissa: inital glucose concentration of the equilibrating fluid which was varied in steps mainly of $10 \mathrm{mg} / 100 \mathrm{ml}$. The length of each horizontal line indicates the number of observations at the corresponding R.Q. At abscissa value 0 and R.Q. value 0.8 , the number of observations was eleven. Figures at tops of experimental results: blood glucose concentration when rat was killed. (After O'CONNOR 1965)

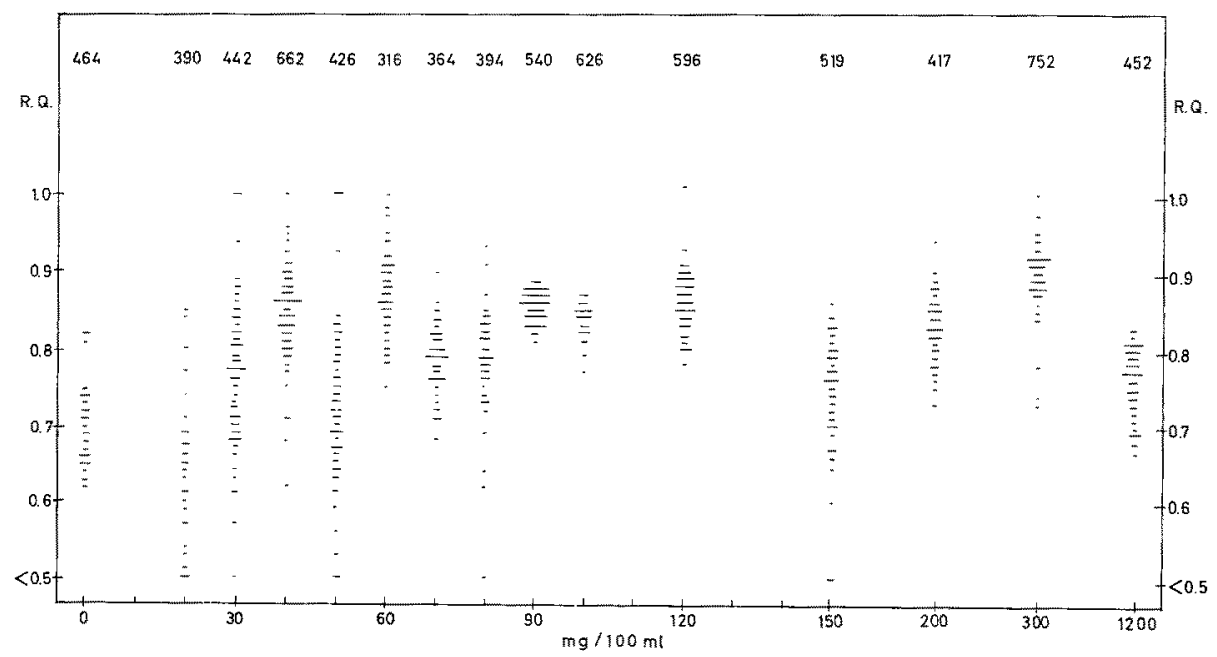

Fig. 1, II: Influence of extracellular concentration of glucose on the R.Q. of diabetic rat kidney slices. Code as in Figure 1, I. Abscissa reading " 1200 " is estimated maximal concentration of glucose in experiments without contacr with an equilibrating solution.

(After O'CONNOR 1965) 
R. Q.'s appear is lower than in normal individuals. It was found, however, that in the diabetic kidney the concentration of extracellular glucose, particularly within the uriniferous tubules, is so high that the equilibrium concentration of glucose in the Ringer solution is approximately $20 \mathrm{mg}$ higher than the initial value. In Figure 1 allowance for this is made by moving the base line of the diabetic graph $20 \mathrm{mg}$ to the

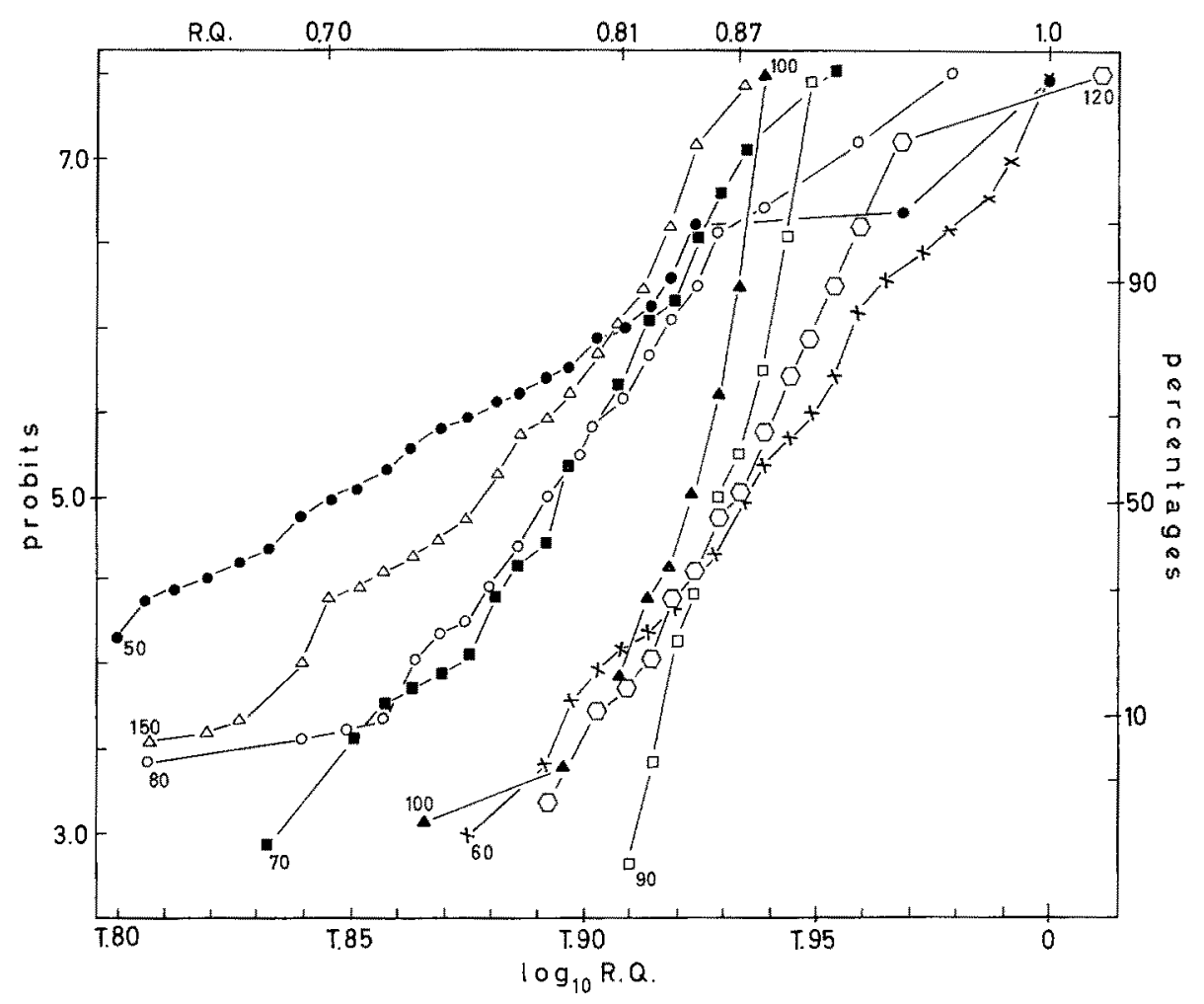

Fig. 2: Influence of glucose concentration on R.Q. of diabetic kidney slices. Abscissa: $\log _{10}$ R.Q. ordinates probits of R.Q. Each line indicates a separate experiment. Number attached to each line: extracellulat glucose in $\mathrm{mg} / 100 \mathrm{ml}$.

right. From a comparison of the two graphs, it is apparent that if normal blood sugar were at, for example, $90 \mathrm{mg} / 100 \mathrm{ml}$ and diabetes were conceived to appear, the capability of burning high proportions of glucose will have disappeared, and glucose must accumulate in the blood or in the reserves.

If the graphs of Figure 1 are compared in detail, it is apparent that within the range of extracellular glucose concentrations in which high R.Q.'s occur there differences occur. For example, at the initial concentration $70 \mathrm{mg} / 100 \mathrm{ml}$ in Figure 1, I, the whole range of R. Q.'s is included in the observed results, but at $90 \mathrm{mg} / 100 \mathrm{ml}$ there are almost no observations below 0.9 . Thus even within the normal blood concentration, the relation is not simple. Probit analysis was used for a more detailed analysis of the results. This method is extensively used for investigating the toxicity of drugs; it 
depends on a development of the binomial distribution of frequencies (FrNNEY 1962). If the percentage of animals dying after application of known concentrations of a drug be plotted against the log of concentration, they fall along an $S$ curve. A table is available by which percentages may be replaced by equivalent "probits". When this is done, the $\mathrm{S}$ graph is converted into a straight line.

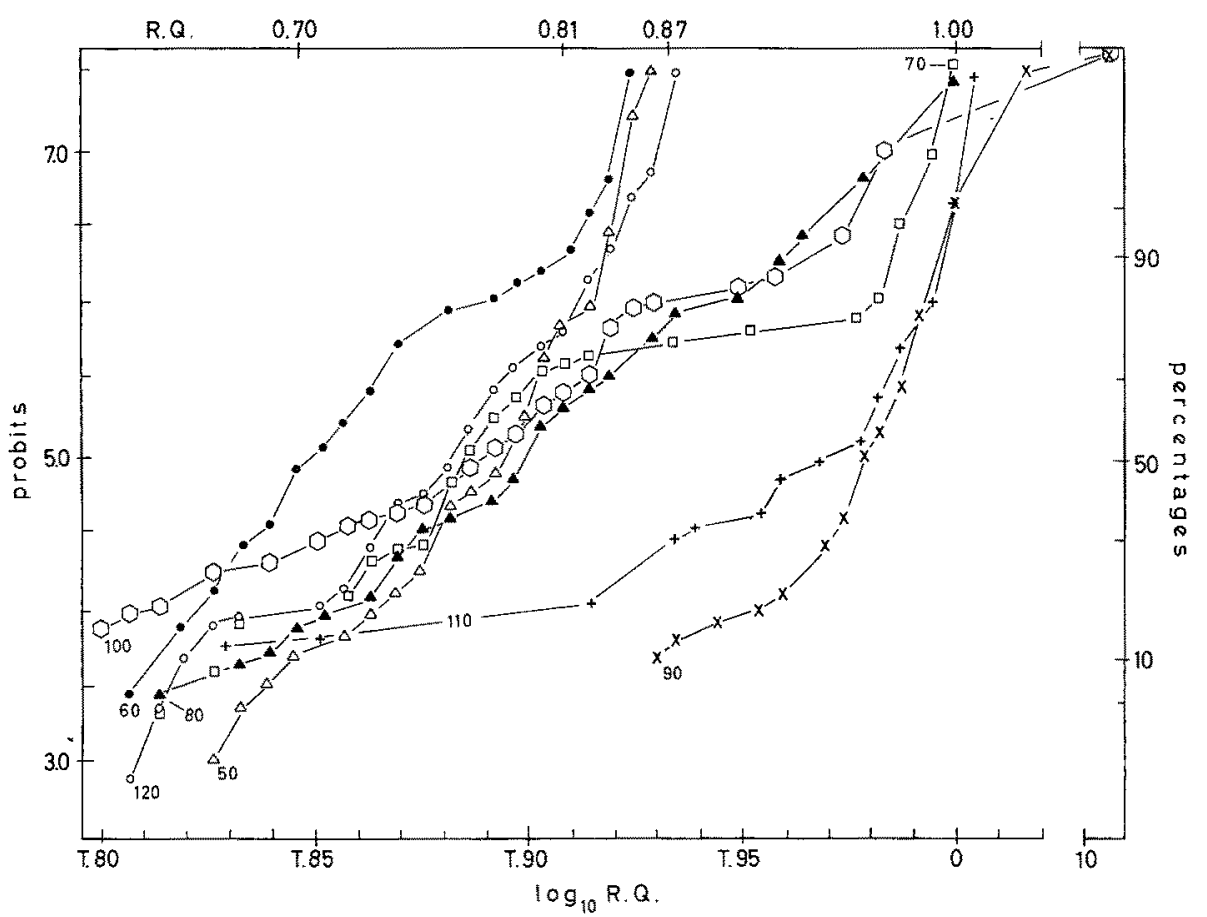

Fig. 3: Influence of glucose concentration on R. Q. of normal kidney slices. Code as in Figure 2

The variation in R.Q.'s mainly depends on the proportions of fat and carbohydrate which are burnt. If there be a competition between them for the availing oxidizing power, then on an analogy between death and survival under the action of a drug, a graph of the probits at each R.Q. against the logarithm of the R.Q.s should in the simplest case be expected to rise along a straight line from R.Q. $=0.7$ to R.Q. $=1.0$. The simplest case is improbable, but if there is any range of $\mathrm{R}$. Q. over which competition prevails, there should be indications of a straight line relation.

Responses of diabetic rats represent the simpler case and are therefore examined first (Fig. 2). Examination of all experiments would only confuse; hence only experiments in which the initial glucose concentration was within normal range and a few representative experiments outside this range are presented. Since little significance can be attached to R. Q.s below 0.6 the abscissa of the graph begins at -1.80 although all recorded results are included in the calculation. From an abcissa value not far from -1.84 , which is close to the $\log$ of the R.Q. of fatty acid, the probit observations for 
$50,70,80$ and $150 \mathrm{mg} / 100 \mathrm{ml}$ converge along straight lines to a point at the approximate abscissa value -1.91 and a probit value of 6.2 . From this point the lines joining the observations radiate out, but almost none of them approaches closely to $0-$ the maximal catabolic value.

A second group of $60,90,100,120 \mathrm{mg} / 100 \mathrm{ml}$ begin close to the abscissa reading -1.91 and at a probit reading about 4.1 ; from this they run to the abscissa reading - 1.93. This is the $\log$ of the R.Q. of glycerol. From this point the probits radiate along approximately straight lines to the final values which are, with few exceptions, less than the R.Q. of glucose. In addition to the scarcity of high values of R.Q.s the striking feature of the graph is that the observations tend to lie along rising straight lines, suggesting that there are competitions for oxidation at all stages.

Figure 3 is the corresponding analysis for normal tissue; the lower moiety does not differ greatly from the diabetic graph. The probit values run approximately along straight lines from the abscissa value corresponding to the R.Q. of fatty acid, to the $\log$ abscissa value T. 91. From this point they diverge into two groups. One set consisting of the observations for 50,60 and $120 \mathrm{mg} / 100 \mathrm{ml}$ run in a group along a straight line to the log value of the R.Q.'s of glycerol. The second set over the same range of the abscissa, curves towards the horizontal, indicating an absence of competition, until again, the R.Q. of glycerol is reached. From this point the graphs rise steeply to R.Q. $=1.0$. This group constists of 70,80 and $100 \mathrm{mg}$. These are all within the range of normal blood sugar concentration. The remaining two experiments on rats with normal blood sugar ranges $(90$ and $100 \mathrm{mg} / 100 \mathrm{ml}$ ) almost completely lack observations in the lower moiety of the graph. More than half of the observations are higher than R.Q. $=0.98$.

A comparison of the graphs in Figure 2 and Figure 3 suggests that there is a barrier corresponding approximately to the mid point of the range of R.Q., to the left of which, under diabetic and normal conditions competition between fatty acid and glucose for combustion takes place. In the diabetic state this barrier cannot ordinarily be passed, and high R. Q.'s are very rare. In the normal state when the intracellular glucose is in equilibrium with the normal blood sugar concentration, there is a free passage through the barrier, but in some cases, in sharp contrast with the diabetic experiments, high R. Q.'s are to be found.

At the basis of this conclusion is the assumption that the exposure to $3 \mathrm{ml} \mathrm{Ringer}$ in the preparatory period does not essentially distort the changes which occur in vivo. It has been found that by using $15 \mathrm{ml}$ Ringer solution, the results are different (O'CONNOR 1965). Thus doubt arises about the confidence which can be placed in results differing only in using a smaller volume. It has, however, been found possible to mount flat sections on the cradles of respirometers, without any contact with extraneous fluid (O'ConNor 1965). Figure 4 presents graphed results obtained with these preparations; three were done with kidney slices and three with liver. In five of these experiments, the segregation of the R.Q. values into two differing sections is very clear; in the sixth, the graph corresponds with the results illustrated in Figure 3, in which the R.Q.'s pass through the barrier between the sections at some concentrations within the normal blood sugar concentrations. There is thus no reason to distrust a correspondence with in vivo conditions. The similarity of the results obtained with 
liver and those with kidney in Figure 4 show that conclusions based on kidney tissue have some general application. Several series have been done with other tissues, but they cannot be considered fully here. It may, however, be stated that any divergences from the results obtained on kidneys are consistent with the known metabolic properties of the organs.

It will be noticed that the location of the "barrier" in relation to R.Q. is close to the R.Q. of protein, as this has been approximately calculated for the whole animal.

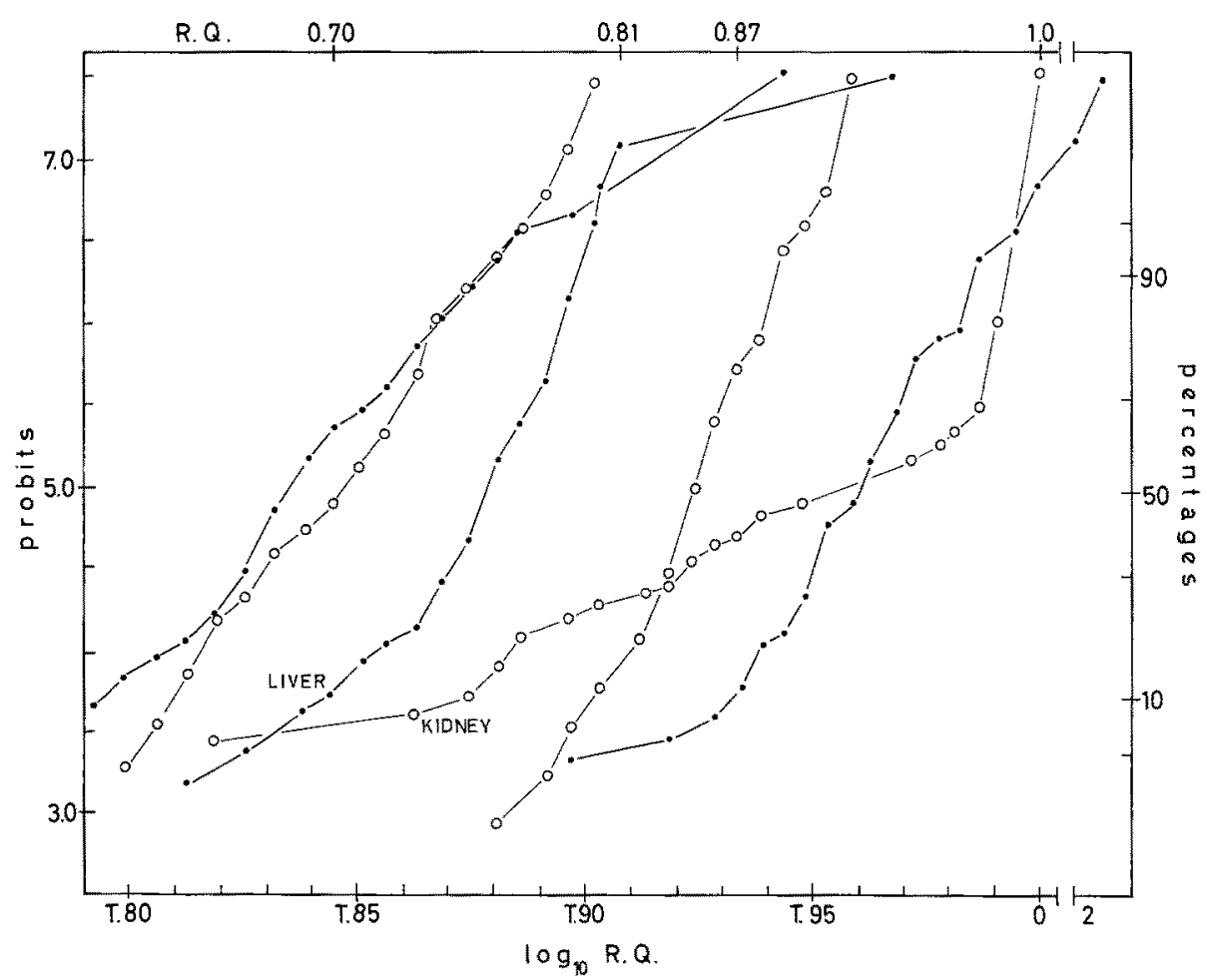

Fig. 4: Relation of probits of R.Q. to $\log _{10}$ R. Q. in liver $(\times)$ and kidney $(0)$ slices having not been in contact with any extraneous fluid

However, as there is nothing known about the protein R.Q. for isolated tissues - and it may well be different - there is no basis for discussion about a possible significance of the coincidence.

The conception of a "barrier" is structural. It implies a difference in the location of the two phases of distribution in the R.Q. The oxidizing enzymes are ordinarily held in the mitochondria, and the complete sequence of decomposition of fatty acid also takes place in the mitochondria. In contrast with this, the acetic acid from the "anaerobic" breakdown of the carbohydrate occurs in the cell fluid. In these conditions it appears that the acetate resulting from the preliminary decomposition of fatty acids coming in close contact with the oxidizing enzymes will have a better access to oxida- 
tion than that arising from carbohydrates. The fact that increases in the rate of oxidation and a fall in R. Q. are associated with the individual fatty acids in an homologous series, indicates that a physical change in fatty acids is responsible for the changes in metabolism. There must, however, be some additional influence of the carbohydrates in facilitating the appearance of high R.Q.'s. for in the diabetic state in which the $R$. Q.'s are persistently low, the oscillations in the intensity of oxidation are at least as marked as when the $R$. $Q$. values vary widely.

In normal conditions high R.Q.'s are associated with the "valleys" in oxygen consumption, but this assertion is not binding. The oscillations in oxygen comsumption are commonly pronounced in diabetic tissues with which high R. Q. are not to be found.

Essential to an understanding of the influence of fatty acids on the intensity of oxidation (and in the normal individual on the associated change in R.Q.) is a comprehension of physical changes in the fatty acids. The temperatures at which the individual fatty acids exhibit their effects are much lower than their melting points; some other characteristic physical property must therefore be responsible. Such a property is their power as amphiphylic substances to form liquid crystals with soap (LAWRENCE 1961). LAWRENCE investigated the temperatures at which the series of fatty acids form liquid crystals with various soaps; he found that their action appeared in an homologous series, with each of the soaps examined. The temperatures were all below the melting points, and in one case were very similar to those at which the fatty acids excercised their metabolic effects. The question arose that if this metabolic effect be due to a formation of liquid crystals, what is the soap?

It has been suggested that the protein of the enzymes might be responsible, but there is no direct evidence, and LAWRENCE (1964) states that it is very improbable. There are, however, in the mitochondria, high concentrations of lipoids, among them lecithin, which is a soap. It has been shown that various lecithinases cause marked falls in mitochondrial oxidation (Kemin \& Hartree 1948, McFarlane 1950, Braganca \& QuAstel 1953, NygaARd 1953, Tookey \& Balls 1956). This is explained if lecithin were necessary to bind the fatty acid into a crystalline scaffold in which the components of the mitochondria are held in close contact. Mitochondria are not constant in bulk. When they become smaller constituents including the oxidizing enzymes must be distributed in the cell fluid and gain access to the products of carbohydrate glycolysis.

Substances containing hydroxyl groups are antagonistic to the formation of amphiphilic liquid crystals. Glucose in sufficient concentration might thus be expected to increase its own oxidation by facilitating contact with the oxidizing ferments. It may be objected that the concentration of free glucose in the cells is commonly very low, but it may well be comparable with the amounts of free fatty acids which it affects. It is also possible that this facilitation of glucose oxidation, which it certainly produces, is a consequence of an action of some of its phosphatic derivatives. About this nothing relevant can be said.

Figure 3 shows that the flattening of the graphs continues to an abscissa value corresponding to the R. Q. of glycerol. It too is a substance which by reason of the large number of hydroxyl groups might be expected to exert a disintegrating effect on the mitochondria. Above the R.Q. value of glycerol the concentration of this substance 
would be expected to fall. This would account for the tendency of all the R.Q.'s above this to revert to an indication of competition.

LAWRENCE (1964) has investigated the relation of glycerol to amphiphilic crystal formation and has obtained satisfactory evidence of its peptizing effect. If this conception of the action of glycerol is correct, it is to be expected that a preparatory ex-

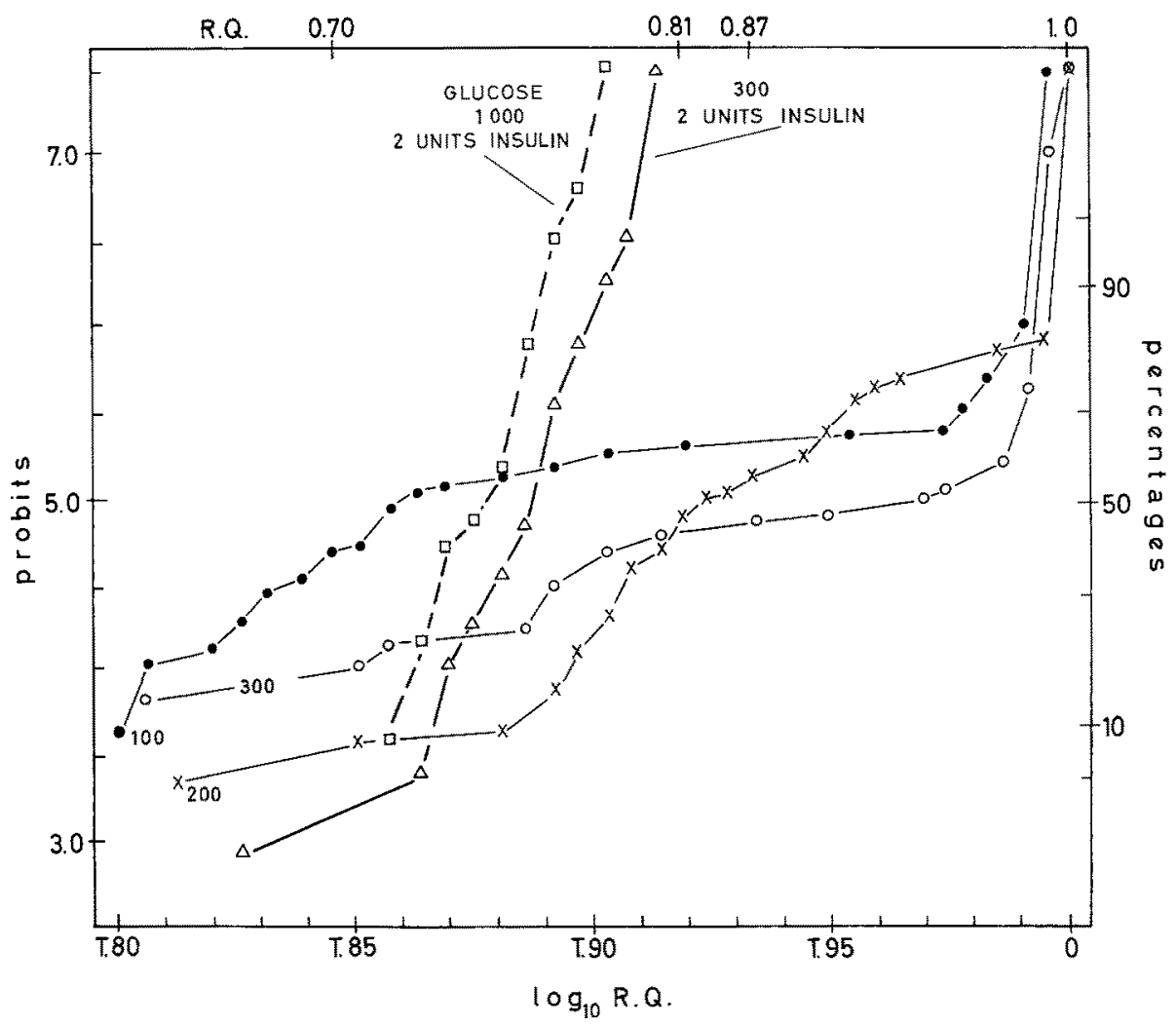

Fig. 5: Influence of glycerol on R.Q. of kidney slices. Abscissa: $\log _{10}$ R. Q. Ordinate: probits of $Q$. R. Each experiment is characterized by a line with a number indicating the concentration of glycerol in $\mathrm{mg} / 100 \mathrm{ml}$ to which the slices had been exposed. Thick line: rat received an injection of two units of insulin. An experiment in which a rat had also received 2 units insulin, but was exposed to $1.0 \mathrm{~g}$ glucose $/ 100 \mathrm{ml}$, is included for comparison

posure to $3 \mathrm{ml}$ solutions of glycerol in Ringer would show the expected influence. Data suitable for this purpose have been collected previously (O'Connor 1964). The probit analysis is presented in Figure 5. It is seen that with the concentrations of glycerol which were used, the barrier has completely disappeared, and particularly with the concentration of $100 \mathrm{mg} / 100 \mathrm{ml}$ all indications of a competition are absent. There is a possible alternative explanation of this action of glycerol. A mass action of the high concentration of glycerol may have resulted in the free fatty acid being removed as neutral fat. In both of these interpretations the importance of the fatty acids in the control of the distribution of oxygen is implied. 
It has been shown that after an injection of insulin, the respiratory quotient is usually fixed. In Figure 5 a probit graph of such an experiment is given, as well as a similar experiment in which an injection of insulin is combined with an exposure to a solution of glycerol. The two graphs are very similar. This suggests that the actions of glucose and of glycerol are of the same nature.

The effect of these two substances in causing a solution of amphiphilic liquid crystals is attributable to the presence in the molecules of a high proportion of hydroxyl radicles. Why there is an upper limit to the concentration of glucose within which glucose is burnt freely is at present speculative. It is known that the formation of amphiphilic crystals depends upon the proportion of the concentrations of the amphiphilic substance and the soap. A theoretical explanation of this has been advanced (WINsor 1954). It might be expected that some related influence of proportion determines an upper limit to the effect of the concentration of glucose in producing the extension of the range of the R. Q.

\section{SUMMARY}

1. Oxygen consumption of rat tissue slices has been followed in a respirometer as the temperature falls, while contact with warm Ringer's solution was avoided. Under these conditions rate of $\mathrm{O}_{2}$-consumption oscillates. Simultaneous observations on $\mathrm{O}_{2}$-consumption and $\mathrm{CO}_{9}$-production demonstrated that the respiratory quotient (R.Q.) also varies sharply within the range of temperatures prevailing within the body. All variations must be taken into account in studying the responses of the whole animal.

2. Experiments were made on slices of rat kidney, which had been exposed for two hours to a small volume of cold Ringer's solution, containing various concentrations of glucose. Wide oscillations in R.Q. were found only when the extracellular glucose concentration lay within the limits of the normal blood sugar level. Above and below this the R. Q.s are low.

3. In experiments with alloxan diabetics rats, this limitation of the range of $R$. $Q$. prevails at all extracellular glucose concentrations above a very low value.

4. Statistical analyses of experimental results show that the course of the R.Q.s is divisible in to two portions. In the lower portion there is a sharp competition between fatty acids and carbohydrates for oxidation; this breaks off at an R.Q. value of 0.8 . Arguments are presented in support of the conception that up to this point, oxidation is carried on inside the mitochondria, the structure of which is based on an amphiphilic crystalline conjunction of fatty acid and lecithin. The partial breakdown of this crystalline structure - under the influence of the hydroxyl containing glucose molecules at a concentration associated with the normal extracellular glucose - allows access of the oxidizing enzymes to the products of glycolysis and, in consequence, the appearance of the upper zone of R. Q.s. 


\section{LITERATURE CITED}

Braganca, B. M. \& Quastel, J. H., 1953. Enzyme inhibitions by snake venoms. Biochem. J. $53,88-102$.

Finner, D. J, 1962. Probit analysis. Univ. pr., Cambridge, 318 pp.

KeILIN, D. \& Hartree, E. F., 1948. Activity of succinic dehydrogenase - Cytochrome system in different tissue preparations. Biochem. J. 44, 205-218.

LAwRENCE, A. S. C., 1961. Polar interaction in detergency. In: Surface activity and detergency. Ed. by K. Durham. Macmillan \& Co., London, 158-192.

- 1964. Personal communication.

Macfarlane, M. G., 1950. Inhibition of succinoxidase activity of mitochondria by Clostridium weldii toxin. Biodsem. J. 47 (Proc. XXIX).

NygaARd, A. P., 1953. Factors inyolved in enzymic reduction of cytodrome c. J. biol. Chem. 204, 655-663.

O'CONNoR, J. M., 1955. Influence of fatty acids and of the adrenal cortex on the course of oxygen consumption with changing temperature. Am. J. Physiol. 181, 89-96.

- 1959. The Basis of the constancy of the body temperature. Proc. R. Ir. Acad. 60 B, 243-214.

- 1960. The action of fatty acids on oxidative metabolism. Proc. R. Ir. Acad.61 B, 187-200.

- 1962. The influence of insulin on the gaseous exchange of isolated tissues. Proc. R. Ir. Acad. 62 B, 101-116.

- 1964. The nature of the influence of fatty acids, glucose and insulin on the respiratory quotient of animal tissue. Proc. R. Ir. Acad. 63 B, 201-215.

- 1965. The relation between the extracellular concentration of glucose and the combustion of glucose in normal and diabetic tissue. Proc. R. Ir. Acad. 64 B, 81-88.

Tookex, H. L. \& Balls, A. K., 1956. The inhibition of succinic oxidase by cottonseed phospholipase D. J. biol. Chem, 220, 15-23.

Winsor, P. A., 1954. Solvent properties of amphiphilic compounds. Butterworths, London, $207 \mathrm{pp}$. 